\title{
The Terrorism: An Anathema
}

\section{Giteemoni Saikia}

\begin{abstract}
In the following article the topic of 'terrorism' has been discussed broad way, with all its pros and cons. Its growth and evolution in a pace, cause, solutions to eradicate by meticulous planning .Also an analysis has been done of terrorism which is prevalent throughout the ages and countries. It is seen that though in ancient times people used terror for their personal benefits when people were mostly uncivilized, illiterate and thus used force to fulfill their appetite but it must be noted that it is seen to suppress and exploit the weak is a common human instinct. For this reason perhaps people used terror or threat in spite of being civilized and educated. Its practical solutions seem to be totally impossible. Now-a-day, government has taken measured steps to check terrorism with iron-hand but its success is still not apparent, as if all aspects to check terrorism is remain a dream.
\end{abstract}

\section{Introduction}

Since early age, terrorism has been the means of attaining power to control or subjugate other domain. Often a small country or tribe is over powered by a more powerful power. Their sovereignty has been trampled and the people are forced to face all kind of hardship to appease the conqueror .Nothing have been changed .In any case, whether in the case of social reformation or to change the basic administrative structure-terrorism remained indispensible.

The word terrorism derives from the French word "terrorisms." It referred to the state terrorism practiced by the French government during the time of reign of terror. The French word in turn derives from Latin verb "terreo"which means "I frighten". But any way, the word terrorism refers to the systematic and sporadic use of terror by some clandestine group. The word bears hundred of definition and its root cause also narrated in various ways. But the common definition of terrorism refers to that violent act against noncombatant which is intended to create fear psychosis among common people -simultaneously, designed to send massage to the administration in power. Another cause of adopting terrorism is the chauvinism which attracts numerous trigger-happy youth to join the arm revolution. Some expert says, it is the religious, political or ideological goal of some hard liner who believe that they can't achieve it through democratic process- choose the path of terrorism. The word terrorism is a label used by a state to delegitimize and devalued the action of the actors so that the general people condemn the action and alienate them. They both blame each other. If one blames other as being invader then another accuses their opponent as terrorist, separatist or fanatics. The state use these terms according to their convenience.

The impact of terrorism is always pathetic; especially it applied to common people. The brutality used in a arm revolution is also apparent. As example-at the time of long march Mao-Tse-Tung ordered to proceed. One woman who had gone into labor had to walk to the night destination with the baby's head dangling out. Next day before dawn, weeping at leaving her baby in a bundle of straw in the empty hut, she had to walk on and fainted wading through icy river. To that extent a revolutionist could terrorize women who are weak and defenseless. The north east has witnessed some appalling brutality of terrorism and the violation of human rights by so called revolutionist.

The most brutal example of state terrorism was set by Robespierre when he ordered his henchmen to eliminate all the enemies of the revolution on $5^{\text {th }}$ September, 1793. The nobles, churchman and those suspected of hoarding food were to be eliminated. The order was carried out -in Loire valley alone 2, 50000 people were killed- a third of the population of the region. Another example is Paris-educated intellectual that notorious Pol Pot. The teenage soldier of Khmer Rouge looked for any one appearing to be well- educated or enjoying wealth and power. They looked for people with soft hands, those who looked well-fed or well -dressed, were pulled out of human stream and interrogated. Anyone who admitted to being one of urban elite- a bureaucrat, a businessman, a doctor, a teacher, a lawyer, or an engineer-was taken away and shot. This was known as" class vengeance", a favorite slogan of the Khmer doctrine" a revolution is not a dinner party" was alone responsible for the One afternoon in May, 1948, a middle aged British major of Suffolk, regiment handed over a key to Rabbi Mordechai Weingarten. It was the key to Zion Gate, one of the seven gates of the old city of Jerusalem. Israel - Palestine conflict began on November, $29^{\mathrm{TH}}, 1947$, the day the General Assembly of the United Nation refused to both states refused to both states sovereignty over the city of Jerusalem. A never ending conflict that the people of both states have shaded blood for the holy city and identity. 
Rouge. doctrine" a revolution is not a dinner party" was alone responsible for the One afternoon in May, 1948, a middle aged British major of Suffolk, regiment handed over a key to Rabbi Mordechai Weingarten. It was the key to Zion Gate, one of the seven gates of the old city of Jerusalem. Israel - Palestine conflict began on November, $29^{\mathrm{TH}}$, 1947, the day the General Assembly of the United Nation refused to both states refused to both states sovereignty over the city of Jerusalem. A never ending conflict that the people of both states have shaded blood for the holy city and identity. doctrine" a revolution is not a dinner party" was alone responsible for the One afternoon in May, 1948, a middle aged British major of Suffolk, regiment handed over a key to Rabbi Mordechai Weingarten. It was the key to Zion Gate, one of the seven gates of the old city of Jerusalem. Israel Palestine conflict began on November, $29^{\mathrm{TH}}, 1947$, the day the General Assembly of the United Nation refused to both states refused to both states sovereignty over the city of Jerusalem. A never ending conflict that the people of both states have shaded blood for the holy city and identity.

.Mao-Tse-Tung the man who mesmerized the world with his death of 70 million people during his tenure. But to his numerous followers he was a great revolutionist and liberator. To overtake all capitalist country and convert China into a most powerful and richest country in the world within a short period, Mao-Tse Tung declared a bizarre program: The Great Leap. He wanted to overtake America within 10 years and Britain in 15 years. He fancied he could achieve it by exporting the food to Russia. People were asked to stay at People commune and work hard. They were forced to work from dawn to dusk-a total working time of 11 hours. They were told to eat food substitutes such as a green roe like substance which grew in urine. The amount of ration allotted to per person had been declined abruptly from $5.1 \mathrm{~kg}$ meat in 1957 per year to $1.5 \mathrm{~kg}$ meat in 1960 . People were starving. Stealing their own harvest leads to severe punishment. Some people were buried alive, others strangled by rope, others had their nose cut-off. One child had his four finger chopped off for trying to steal a scrape of unripe food. Two children were hanged by wires runs through their ears for stealing food. During 1960 six case of cannibalism came into light including that of a couple who strangled and ate their eight years son. Such was the atrocities perpetrated by a state to common people.

Genocide committed by Adolf Hitler during World War 2 is also a kind of state terrorism according to theorist. Nothing is more terrorizing than the liquidation of Jews in Warshaw Ghetto in the history of world terrorism where the victims had to dig their own grave. More than 500000 people were killed. His henchman Eichmann alone responsible for killing 6000000 people. In a ravine outside Kiev, capital of the Ukraine, called Babi Yar the Nazis butchered 200000 Jews there.

On the morning of 16 March, three companies of American troops were sent on a search and destroy operation in the My Son area near Quang Ngai. Their main objective was to find out Vietcong and killed. The Soldiers were from the $11^{\text {th }}$ infantry Brigade, American division. Their target was the Vietcong's $48^{\text {th }}$ battalion which intelligence believed was operating out of a hamlet marked on American maps as My Lai 4. Under the command of Lt William L. Cally the $1^{\text {st }}$ platoon stormed into the hamlet -shooting anyone who tried to escape, raping, bayoneting, shooting livestock, destroying crops and houses. Cally fired relentlessly filling up the ditch with human corps. One two years child miraculously survived, crawling over the corpses, tried to climb out of the ditch. Cally grabbed him, shot and the threw his tiny body into ditch. According to combat photographer Ronald Haeberle and army reporter Jay Robert, they had witnessed most appalling carnage of their life. One soldier, after raping a girl, put his rifle into her vagina and pulled the trigger. The brutality and hostility inflicted upon innocent villagers still remained as stigma to the civilized world.

Religious terrorism is rooted in faith base belief. It is assumed that it took its root in $7^{\text {th }}$ century when Prophet wrote a intimidating letter to king of 'Oman', JAIFER, and HIS BROTHER' Abd Al-Jalandi to embrace ISLAM. The interpretation of the letter given bellow- In the NAME of Allah, The Most Beneficent, the Most Merciful.

Peace be upon him who follows true guidance; thereafter I invite both of you to the Call of Islam. Embrace Islam. Allah has sent me as a Prophet to all His creatures in order that I may instill fear of Allah in the hearts of His disobedient creature so that there may be left no excuse for those who deny Allah. If you two accept Islam, you will remain in command of your country; but if you refuse my Call, you've got to remember that all your procession are perishable. My horseman will appropriate your land, and my Prophet hood will assume preponderance over your kingship.

Tuesday September 11, the terrorist hijacked four plans and two of them had crashed into most prestigious building popularly known as twin tower of world trade center. More than 3000 people killed in that holocaust .The whole operation was masterminded by the Al-Qaida and Muhmmad Atta was the ring leader. It was most daring act of terrorism designed for the maximum impact. The plan was carrying one lakh liters of fuel. The building immediately caught fire and collapsed within hours. The master mind behind this infamous operation was the tall rich civil engineer turned most dreaded terrorist - Osama-bin-Laden, the chief of AlQuida. Osama was killed by American S.E.A.L commando on 2-5-2012 at Abbotrabad in Pakistan. On February 21,2002,the world viewed the most horrifying video in the internet of all time- the slaughter of Daniel 
pearl, a citizen of both the United states and Israel. He was the South Asia Burea Journal. The video showed two men holding his legs other one ripping off his neck. It was so appalling that one cannot watch it twice.

u chief of the Wall Street Journal. The video showed two men holding his legs other one ripping off his neck. It was so appalling that one cannot watch it twice.

Another name in the world terrorism is a one eyed stocky war veteran Mullah Omar. He fought for the mujhadeen against Soviet Red army and Afghan communist. He was wounded and lost one eye. He returned to his native place and became a imam in a local mosque and ran a madrassa. It so happened that two Afgan boys were abducted, viciously raped and killed by a gangster turned Mujhadeen check post commander. With a small band of Taliban ( student), Mullah Omar rushed to the spot and dismantled the check post, killing some of them on the spot. The people started worshipping him as protector. In 1966 he was appointed Amir-UlMomineen or commander of faith by a grand assembly called shoora of 1500 religious scholar. Within two years Taliban occupied 90 percent of Afghanistan. Taliban refused to allow women to step out their house even go to the market and refused to allow the girl to attend the school. Those who disobeyed punished severely in public place. The men were hanged at goal post of a football field as exemplary punishment.

The north east tested its first tincture of hostility on non-combatant after the subjugation of ASSAM through Mandau treaty, signed on February 1826 between Major General Archibild Campbell, Thomas Campbell Watson civil commissioner and Admiral Henry Dutchi Sads as one part and Burmese representativesMingimaha-men-halah-khyan-tyan -ungi and Mingimaha-menhalah-thi-tha-thu as other. In the late 1828, Gamdhar Kunwar blew the first bugle of war against British imperialism in the north east. On $14^{\text {th }}$ April 1829 a band of 500 Khasis attacked and killed two British officers. Some prominent person like Piali Phookan, Piali Baruah, Mania Khargharia, Jeuram Dulia Baruh, tried to revolt against British but failed. Pail Phookan and Piali Baruah were hanged on the charge of raise war against Britsh on the bank of Sibsagar tank. Though the great endeavor of two great sons of Assam failed, the martyrdom of these two sons of Assam marked as the first spark of arm revolution of North -East.

Naga's resentment germinated in the year 1832 when 1500 army, including 800 coolies, led by two British army officer visited the Angami region. The Angami resisted but with the superior weaponry British repulsed the attacked. In 1847, Angami Naga massacred a group of Indian sepahi or sepoy and that paved the way for the Britsh to renew the full fledged campaign against Naga. Thus a new era of history of insurgency took its birth in the north east. Naga National Coauncil and its chief Angami Zapu Phizo proclaimed Naga independence on Pakistan independence day: $14^{\text {th }}$ August 1947. In response to Phizo's call, the Naga boycotted the general election. Phizo ordered his cadre to eliminate Sakhira, his aide and nephew on the charge of being traitor. Sakhira was brutally killed and the Prime Minister Nehru ordered the army to crush the revolt. Thenceforth the drainage of human blood continued in north east and it begot many more insurgent groups in the following years.

The insensible act of infanticide committed by Ulfa activists on Independence Day is indescribable. Fifteen children were bombed. On $4^{\text {th }}$ December 1990 a large grave was found with fifteen decomposed bodiesa concrete evidence of genocide committed by Ulfa. There are many more instances of killing innocent people as such murder of Sanjay Ghosh, sixteen year old girl Rashmi Bora, ten years old Sabnam Kalita and the murder of journalist Kamala Saikia. North-East has been enduring the wrath of terrorism since the Gamdhar fired the first shot of rebellion. Now the big Steps that can be taken---- Now the big question is how to check this incessant flow of human blood and wastages human resource. The following measures can be taken to check this flow.

Sometimes a states sponsors terrorism by funding and harboring a terrorist organization for their political goal. But the same alley later on proves Frankenstein after the war. Musharaf himself confesses in his book "In the line of fire" that "we-The United States,Pakistan,Saudi Arabia and all those who were allied with us in the Afghan Jihad created our own Frankenstein". Osama-Bin-Laden and Mullah Omar are the products of C I A. The international court should bring the creator of these two monster to the justice. Another instance is Jarnail Singh Bhindrewalah who created havoc in Punjab during eighties- finally killed in operation blue star. He was a product of congress government.

The general people should be enlightened with the real meaning of the scripture. The misinterpretation of the text creates radicals and fanatics. The word JIHAD means "to struggle". To struggle to survive in this competitive era, to struggle to pass in the examination are also one kind of jihad. But this particular word has been translated to a certain community in misleading way. This causes disaster.

The media must stop publishing the propaganda of such extremist group.

International community should take a collective decision to bring them to the negotiation table.

Above all if the world stand together to fight against this barbarism, a civilized world would survive otherwise the men would witness a chaotic world where only the hooligans and barbarians rule and the innocent people would be the victims. 


\section{References:}

[1] Afghanistan and 9/11 by 1 .Anand Giridharadas

Ajay Shukla

Rahimulla Yusufzai

John Jennings

Rifaat Hussain

J.N. Dixit

Julie Sirrs.

[2] In the Line of Fire by Parvez Musharraf. [pages:209,210,228]

[3] Stranger of the mist by Sanjoy Hazarika

[4] The sealed nectar by Saifur rahman al Mubarakpuri[page-360]

[5] The World Worst Atrocities by Nigel Cawthorne

[6] [Pol Pot:page-159,153][My Lai:page-51][Robessperrie:page-54,109,127]

[7] O Jeru-salem! By 1.Larry Collins.

2.Dominigue Lapierre [page: $\{$ prologue $\} \mathrm{xvi}$

[8] Mao by1. Juang Chang

2.John Halliday. 